\title{
講
}

\section{アメリカにおける臨界安全管理の基準化 \\ Standardization of Criticality Control in USA}

By C.L. BROWN*

（1972年 5 月 23日 国立教育会館にて諈演）

座長 東大·清澒量平氏

\begin{abstract}
アメリカでは，1918年に初めて技術基準委員会 (American Engineering Standards Committee) が設置されて以来，1928年にはこれが桩大改組されて アメリカ基準協会 (American Standards Association）となり，各種の工業規格や技術基準の制定を行 なってきた。その後1966年には主として財政面の改善 を図るための改組により USA Standards Institute
\end{abstract}

\begin{abstract}
が設立され，さらに1969年に American National Standards Institute (ANSI) と改称されて今日至 って括り，各專門分野の学協会などから提出される基 準案を検討し，関連する各方面の合意を得た上で American National Standard として制定する活動 を行なっている。

この基準協会には現在 Table 1 に示すような13の
\end{abstract}

Table 1 ANSI Nuclear Technical Advisory Board Committees

\footnotetext{
N11: Basic Materials and Materials Testing for Nuclear Applications (Amer. Soc. for Testing \& Materials)

N12: Nuclear Terminology, Units, Symbols Identification, and Signals (At. Ind. Forum)

N13: Radiation Protection (At. Ind. Forum)

N14: Transportation of Fissle and Radioactive Materials (Amer. Insurance Assoc.)

N15: Methods of Nuclear Materials Control (Inst. of Nucl. Mater. Management)

N16: Nuclear Criticality Safety (Amer. Nucl. Soc.)

N18: Nuclear Design Criteria (Amer. Nucl. Soc.)

N41: Controls, Instrumentation and Electrical Systems for Nuclear Power Generating Stations (Inst. of Elect. and Electronics Eng.)

N42: Nuclear Instruments (Inst. of Elect. and Electronics Eng.)

N43: Equipment for Non-Medical Radiation Applications (Nat. Bur. of Standards)

N44: Equipment and Materials for Medical Radiation Research (Bur. of Radiol. Health)

N45: Reactor Plants and Their Maintenance (Amer. Soc. of Mech. Eng.)

N101: Atomic Industry Facility Design, Location, Construction, and Operation Criteria (Amer. Inst. of Chem. Eng.)
}

Note: ( ) indicates the secretariat organization

原子力関係尃門委員会 (Nuclear Technical Advis. ory Board Committees) があるが，その中のN16委 員会が臨界安全管理に関するすので, アメリカ原子力 学会(ANS) がその幹事学会 (secretariat) となっ ている。この分野では Table 2 に示すと拈り, 現在
までK 4 件の基準が制定出版されているが，それらの 概要は次のようなものである。

* Battelle Pacific Northwest Laboratory, Richland, Wash., USA. 
Table 2 Approved and Proposed Standards on Nuclear Criticality Safety (N16 and ANS-8)

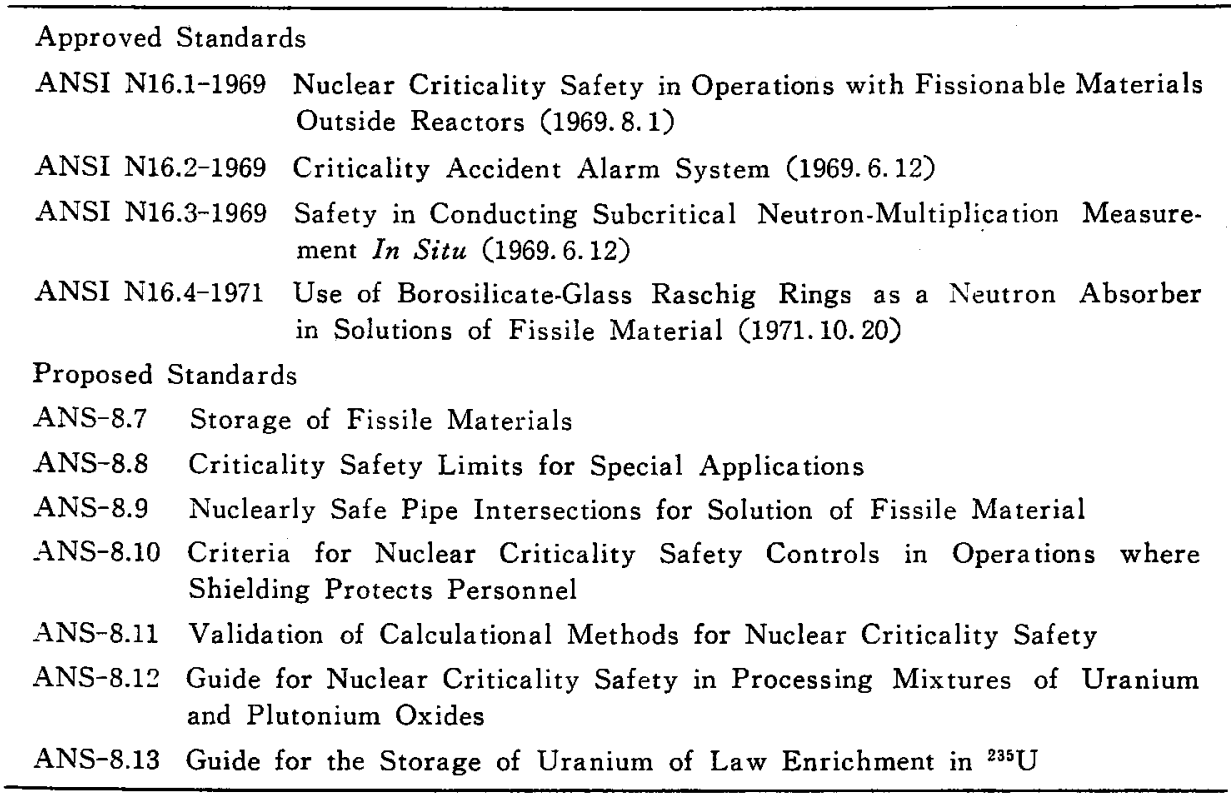

\section{1 原子师外における核分裂性物質取扱い} の臨界安全 (ANSI N16.1-1969: American National Standard, Nuclear Criticality Safety in Operations with Fissionable Materials outside Reactors)

この基隼は核分裂性物質を原子炬外で取り扱う操作 飞適用されるるので, 臨界安全確保のための責任の明 確化, 安全解析, 作業規定, 物䁲管理, 作業の監 督, 緊急 時の処居などの管理組織上の事項と，臨界安全上の制 限因子, 2 重偶発性の原則および形状寸法制限の適用, 中性子吸収材の使用, 未臨界極限值*の決定などの技術 的事項について一般的原則が定められ，さらに水溶 液,スラリー拈よ゙金属の単一ユニットについて，質 量, 円筒直径, 平板厚さ, 濃度などに関する未臨界極限 值が与えられている。また，ウラン濃縮度の制限と他 の因子の制限を併用する場合として，濃縮度 $5 \%$ 以下 の金属拈よび酸化ウランと水との格子系に対する未臨 界極限值が，質量，円筒值径，平板厚さ，体積および235U の面積密度について濃縮度の関数としてグラフでち られている。

\section{2 臨界事故警報系（ANSI N16. 2-1969:}

American National Standard, Criticality Accident Alarm System)
核分裂性物質の取扱い，貯蔵势るいは処理が行われ るすべての作業区域について臨界警報系の設置を検討 する必要があるとし，異常放射線の検出，それにもとづ く警報括よび検出警報系の信頼性についての原則が定 められ，また検討すべき区域の指定，放射線検出レベ ル，検出器の感度拉よび配置，試験検查法などに関する 事項が規定されている。また，緊急時の処置㸵よび事 故後の解析評価のための措置についても述べられてお。 り，付録として 系の検討例が示されている。

\section{3 未臨界系中性予增倍率の現場測定実験} (ANSI N16.3-1969: American National Standard, Safety in Conducting Subcritica! Neutron-Multiplication Measurements In Situ)

核分裂性物質を工業規模で取り扱引際儿，实際の配 置について臨界安全上の目安を迅速に与兄るために行 う中性子増倍率の現場測定実験について，実験の安全 管理,䒾置の安全確認拉よび操作上の遵守事項が示さ れている。

* 原語は subcritical limit; 他の関係する諸変数 がすへてて臨界に対して最適な值をとったとしても， 核分裂性物質を含む系が末臨界に保たれるような ある指定された変数の極限値と定義されている。 
4 核分裂性物質を含む溶液における中性 子吸収材としてのホウケイ酸ガラス製 ラシヒリングの使用(ANSI N16.4-1971: American National Standard, Use of Borosilicate-glass Raschig Rings as a Neutron Absorber in Solutions of Fissile Material)

核分裂性物質を含む溶液の臨界安全管理における主 要な手段としてホウケイ酸ガラス製のラシヒリンダを 中性子吸収材に使用する場合について，使用上の条 件,ラシヒリングの製造仕様, 溶液容器の設計仕様, 保 守検査の条件などが示されており，また，標準仕様の ラシヒリングを24，28および32\%の体積率で充媜した 場合に対する ${ }^{235} \mathrm{U}$ 括よび $\mathrm{Pu}\left({ }^{239} \mathrm{Pu} \geq 50 \% ;{ }^{241} \mathrm{Pu} \leq\right.$ $15 \%)$ の最大許容濃度が与光られている。また付録と して，ガラスに含まれる $\mathrm{B}_{2} \mathrm{O}_{3}$ の定量法,ラシヒリン ク゚の機械的強度試験用回転ドラムの設計例括よびラシ ヒリングを充埧した溶液容器の倹查報告書式の例がつ けられている。

上記 4 件の基準のほかても，Table 2 に示されてい る 7 つの項目について基準原案の作成または検討の作 業が ANS-8 小委員会 (Fissile Materials outside Reactors) 内のそれぞれのワーキング・グループによ
って進められている。すなわち, ANS-8.7では，核 分裂性物質の貯蔵に関する指針として, 種々の濃縮度 のUあるいは種々の同位体組成の $\mathrm{Pu}$ の金属または酸 化物を，立方配列で眝葴する場合に対して，減速度の 範围(例壳ば H/U トの個数と配列間隔の関数としてニニットの最大許容 質量を表で示している。ANS-8.8 は濃縮度が $5 \%$ 以 下のUの場合に，臨界管理上の前提としての減速度の. 制限に関する基準を定めようとするるのであり，また ANS-8.9 は最適濃度(減速度)の溶液が入った交差す るパイプの臨界安全条件をUの濃縮度や Pu 同位体組 成の広い範用にわたって与えようとするものである。 さらに ANS-8.10は再処理などの場合のように操作員 が厚い遮蔽壁によって防護されている場合の臨界安全 設計に関する原則を示すことを，また ANS-8.11は臨 界安全評価のための核計算法の標準化を目的としたも のである。ANS-8.12 では，軽水炬あるいは高速炉用， の $\mathrm{Pu}$ 燃料の取扱いK関して，Pu 含有率が $1 \sim 30 \%$ の範囲にわたる Pu と天然U混合燃料の臨界安全パラ メータを指定しょうとしており，ANS-8.13では濃䌕 度 $5 \%$ 以下のUの場合に, 未臨界ニニット間の相互干 渉の評価法について指針を与えようとしている。

アメりカ基準協会 (ANSI) の原子力関係専門委員 会としては上記の臨界管理に関するN16委員会のほか。.

Table 3 Approved and Proposed Standards on Methods of Nuclear Materials Control (N15)

Approved Standards

ANSI N15.1-1970 Classification of Unirradiated Uranium Scrap (1970.1.5)

ANSI N15.2-1971 Record and Reporting Units for Nuclear Materials Control (1971. 11.1)

ANSI N15.3-1972 Physical Inventories for Nuclear Materials (1972.2.17)

ANSI N15.4-1971 A Guide to Practice, Nuclear Material Control Systems for Conversion Facilities (1971.10.20)

ANSI N15.5-1972 Statistical Terminology and Notation (1972.5.24)

ANSI N15.6-1972 Analytical Standards for Accountability of Uranium Tetrafluoride (1972.4.20)

ANSI N15.7-1972 Analytical Standards for Accountability of Uranium Hexafluoride (1972.4.20)

Proposed Standards

ANSI N15.8 Nuclear Materials Control Systems for Nuclear Power Reactors, A. Guide to Practice

ANSI N15.9 A Guide to Practice, Nuclear Materials Control Systems for Fuel Fabrication Plants

ANSI N15.10 Classification of Unirradiated Plutonium Scrap

ANSI N15.11 Auditing Nuclear Material Statements 
にもこの問題に関連があるものとして，核分裂性およ び放射性物質の輸送に関するN14委員会之核物質管理 飞関するN15委員会がある。N14委員会により現在ま でに制定された基準は，UF $\mathrm{UF}_{6}$ の輸送容器に関するも の (ANSI N14.1-1971: American National Stan. dard, Packaging of Uranium Hexafluoride for Transport）が 1 件のみであるが，N15委員会からは Table 3 に示すように, すでに 7 件のものが制定さ れ，任か 4 件のるのが提案されている。

前述のよらに，ANSI に的ける基準制定の作業は 各分野ごとの幹事学協会の専門家ダループが中心とな って進められているが，参考のために現在のアメリカ 原子力学会基準委員会(ANS Standards Committee) の構成を Table 4 亿紹介して护く。

Table 4 ANS Standards Committee

Section 1 Subcommittees (N15, N16)

ANS-1: Performance of Critical Experiments ANS-3: Reactor Operations ${ }^{\dagger}$

ANS-8: Fissionable Materials outside Reactors ${ }^{\dagger}$ (N14)

ANS-14: Operation of Pulse Nuclear Reactors

ANS-15: Operation of Research Reactors ${ }^{\dagger}$

Section 2 Subcommittees (N18)

ANS-2: Site Evaluation

ANS-4: Reactor Dynamics and Control

ANS-5: Energy and Fission-Product Release

ANS-13: Fuel Assemblies Criteria ${ }^{\dagger}$

ANS-18: Environmental Impact Evaluation

ANS-30: Power Plant Systems and Components (N41)
Section 3 Subcommittees (N13, N43, N44)

ANS-6: Shielding ${ }^{\dagger}$

ANS-9: Nuclear Terminology and Units (N12)

ANS-10: Mathematics and Computation ${ }^{\dagger}$

ANS-11: Radioactive Materials Handling Facility and Specialized Equipment ${ }^{\dagger}$ (N101)

ANS-12: Materials ${ }^{\dagger}$ (N11)

ANS-16: Isotopes and Radiation ${ }^{\dagger}(\mathrm{N} 42)$

Section 4 Subcommittes (N45)

ANS-20: Power Reactors Systems Engineering ANS-21: PWR Design Criteria ANS-22: BWR Design Criteria ANS-23: GCR Design Criteria ANS-24: LMFBR Design Criteria
Note: ( ) indicates the ANSI Nuclear Technical Advisory Board Committee for which the Section or Subcom- mittee Chairman is the ANS Representative.
† indicates the Subcommittee sponsored by the corres- ponding ANS Division or Technical Group.

いずれにせよ技術基準の制定は，いたずらに形式を 整えることが本旨ではなく，むしろ実際の業務にたず さわる各グループからの要請に応じて進められるべき であり，また基準制定の段階では関係するすべてのグ ループの合意を得ておくことが大切なことである。

付記：ANSI および ANSのアドレスは, American National Standards Institute, Inc., 1430 Broadway, New York, N.Y. 10018, U.S.A. および American Nuclear Society, 244 E. Ogden Avenue, Hindsdale, I1l. 60521, U.S.A. です。必要の場合はそれぞれへ捄問合わせ下さい。

（1972年10月31日 東大·工 清瀬量平抄訳）

\section{○原子力産業より放出される放射性核種の○ 環境における挙動シンポジウム}

$\mathrm{IAEA} \cdot \mathrm{OECD}$ WHO 共同で標記シンポジウムが開 催され，論文提出と会議参加者を募集している。 O1973年 5 月14〜18日（於フランス・Aix-en-Provence） ○討議議題

(1) Sources and nature of releases of radionuclides in the nuclear industry

(2) Projected production and releases of radionuclides of regional and global character, their behaviour in the environment and their impact, (e.g. ${ }^{3} \mathrm{H},{ }^{85} \mathrm{Kr}$, ${ }^{129} \mathrm{I}$, etc.)

(3) Environmental transfer mechanisms and concentrating processes

(4) Application of mathematical models to the cycling of radionuclides and for estimating the resultant radiation dose to man.

(5) Environmental capacity for safely receiving radionuclides.

(6) It is proposed that at the conclusion of the Symposium a panel be organized to discuss the procedures, techniques and information needed to determine the capacity of the environment to receive safely radioactive materials on a local, regional and/or global basis. The need for regional and international co-operation for collection and assessment of data on releases of radionuclides to those sectors of the environment where they may go beyond national boundaries will also be discussed.

○本論文 (英文 4 部) 48年 3 月 12 日

○提出先 (二100)東京都千代田区嘈ヶ関2-2-1 (Tel. 03-581-5271) 科学技彷庁原子力局国際協力課 